\title{
Correction to: Dynamic simulation of continuous mixed sugar fermentation with increasing cell retention time for lactic acid production using Enterococcus mundtii QU 25
}

\author{
Ying Wang ${ }^{1,2+}$, Ka-Lai Chan ${ }^{2 \dagger}$, Mohamed Ali Abdel-Rahman ${ }^{3,4}$, Kenji Sonomoto ${ }^{3}$ and Shao-Yuan Leu ${ }^{2 *}$ (D)
}

\section{Correction to: Biotechnol Biofuels (2020) 13:112}

https://doi.org/10.1186/s13068-020-01752-6

Following publication of the original article [1], the authors identified an error in Fig. 1. The correct figure is given below.

The original article has been corrected.

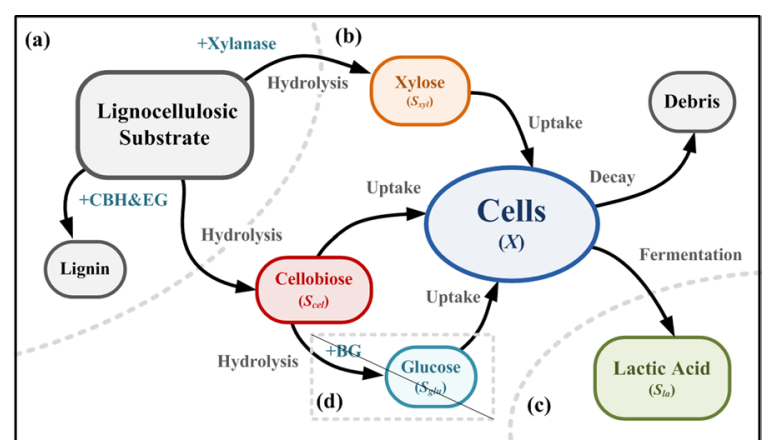

Fig. 1 Conceptual diagram and model structure of the continuous lactic acid co-fermentation process with membrane separation and selected enzyme combination for preventing carbon catabolite repression; a hydrolysis system; $\mathbf{b}$ fermentation; $\mathbf{c}$ membrane separation; and $\mathbf{d}$ pathway to be cut-off to prevent carbon catabolite repression (CCR)

\begin{abstract}
Author details
1 Department of Biological Science, College of Life Sciences, Sichuan Normal University, Chengdu 610101, Sichuan, China. ${ }^{2}$ Department of Civil and Environmental Engineering, Hong Kong Polytechnic University, Kowloon, Hong Kong. ${ }^{3}$ Laboratory of Microbial Technology, Division of Systems Bioengineering, Department of Bioscience and Biotechnology, Faculty of Agriculture, Graduate School, Kyushu University, Motooka, Nishi-ku, Fukuoka, Japan. ${ }^{4}$ Botany and Microbiology Department, Faculty of Science (Boys), Al-Azhar University, PN:1 1884, Nasr City, Cairo, Egypt.
\end{abstract}

Received: 18 July 2020 Accepted: 18 July 2020

Published online: 09 August 2020

\section{Reference}

1. Wang Y, Chan KL, Abdel-Rahman MA, Sonomoto K, Leu SY. Dynamic simulation of continuous mixed sugar fermentation with increasing cell retention time for lactic acid production using Enterococcus mundtii QU 25. Biotechnol Biofuels. 2020;13:112

\section{Publisher's Note}

Springer Nature remains neutral with regard to jurisdictional claims in published maps and institutional affiliations.

The original article can be found online at https://doi.org/10.1186/s1306 8-020-01752-6.

*Correspondence: syleu@polyu.edu.hk

${ }^{\dagger}$ Ying Wang and Ka-Lai Chan contributed equally as co-first authors in this work

${ }^{2}$ Department of Civil and Environmental Engineering, Hong Kong

Polytechnic University, Kowloon, Hong Kong

Full list of author information is available at the end of the article

c) The Author(s) 2020. This article is licensed under a Creative Commons Attribution 4.0 International License, which permits use, sharing, adaptation, distribution and reproduction in any medium or format, as long as you give appropriate credit to the original author(s) and the source, provide a link to the Creative Commons licence, and indicate if changes were made. The images or other third party material in this article are included in the article's Creative Commons licence, unless indicated otherwise in a credit line to the material. If material is not included in the article's Creative Commons licence and your intended use is not permitted by statutory regulation or exceeds the permitted use, you will need to obtain permission directly from the copyright holder. To view a copy of this licence, visit http://creativecommons.org/licenses/by/4.0/. The Creative Commons Public Domain Dedication waiver (http://creativecommons.org/publicdomain/zero/1.0/) applies to the data made available in this article, unless otherwise stated in a credit line to the data. 